Revue d'études américaines. American Studies Journal

$2 \mid 2017$

(Hi)stories of American Women: Writings and Rewritings / Call and Answer: Dialoguing the American West in France

\title{
An Interview with Barry H. Lopez
}

\section{Claire Cazajous-Augé}

\section{(2) OpenEdition \\ Journals}

Electronic version

URL: https://journals.openedition.org/transatlantica/10433

DOI: $10.4000 /$ transatlantica. 10433

ISSN: $1765-2766$

Publisher

Association française d'Etudes Américaines (AFEA)

\section{Electronic reference}

Claire Cazajous-Augé, "An Interview with Barry H. Lopez", Transatlantica [Online], 2 | 2017, Online since 19 April 2019, connection on 01 February 2023. URL: http://journals.openedition.org/transatlantica/ 10433 ; DOI: https://doi.org/10.4000/transatlantica.10433

This text was automatically generated on 1 February 2023.

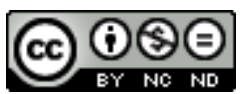

Creative Commons - Attribution-NonCommercial-NoDerivatives 4.0 International - CC BY-NC-ND 4.0 https://creativecommons.org/licenses/by-nc-nd/4.0/ 


\title{
An Interview with Barry H. Lopez
}

\author{
Claire Cazajous-Augé
}

Barry H. Lopez is an essayist, author and short story writer. His texts focus on the relationships between nature and human culture. He is the author of of Wolves and Men, Crossing Open Ground, and of several collections of fiction, including Winter Count and River Notes. He won the National Book Award for Arctic Dreams (1986).

Claire Cazajous-Augé: I would like to start this interview with a question on the use of science in your texts. You often resort to scientifically informed descriptions in order to explain natural phenomena, such as the changing of the seasons at the North Pole and Northern lights. However, instead of using science as a tool for appropriation, you show how it can renew our wonder for the nonhuman. I have the impression that the more you know, the more amazed you are.

Barry Lopez: It is the case that the more I know, the more amazed I am at the complex set of relationships we call the natural world. As for the kind of scientific research I do, I believe carefully attending to what the sciences offer us, with their unique and highly illuminating inquiry into the natural world, not only helps me understand a larger picture but it would not be ethical or responsible of me to ignore this information. The goal is to provide both figurative images for the reader and well-grounded, empirical information, to try to fully inform the reader.

CCA: Many narrators of your nonfiction books challenge their own knowledge and values. Scott Slovic notes that the narrative pattern of your texts is to "assume ignorance or limited awareness to begin with, then proceeds to enact a gradual and almost linear progression toward a deepening awareness" (1992, 153). The same applies to your short stories. Indeed, many of your characters are scientists, biologists, or historians who, as in Desert Notes, fail to understand the animals and the wild places they encounter. They learn to go beyond the threshold that separates the Western and the non-Western visions of the world. Is there an urgency to reintroduce-and preserve-mystery and wonder in our conceptions of the natural world?

BL: I think there is an urgency here, to reintroduce readers to their origins in the natural world. The goal of much of what I do, I think, is to emphasize the underlying mystery of what we take for granted in the natural world, and to suggest that our fate still lies as much or more with this than with technology. 
CCA: In an essay entitled "The Naturalist," you write that the contemporary naturalist does not consider the natural world as an object of scrutiny that they should feel compelled to explain. They have to engage with it, to create an "empirical immersion" with the nonhuman world, in order to perceive its mystery. I was wondering if the numerous details you give in your descriptions are a means to invite your readers to have a firsthand experience with the natural world instead of having an abstract relationship to it.

BL: Yes, I would say that the reason I use so much detailed information in writing about the natural world is to draw the reader deeper into that world and to increase the reader's level of intimacy with it. As with other things in life, increased intimacy enhances a sense of wonder, mystery, and appreciation.

CCA: In Arctic Dreams, you intimate that Eskimo languages convey a better sense of intimacy with the land than Indo-European languages. Is this one of the reasons why you sometimes use Eskimo words without trying to translate them?

BL: It's generally true that indigenous languages reflect a more intimate relationship with the complexities of a particular landscape than would Indo-European or other outlander languages. My use of indigenous terminology is an effort to, 1) make the reader feel more present to whatever environment it is I am describing; 2) to suggest to the reader that we do not have, in the languages that most of us are more familiar with, any adequate terminology to describe certain aspects of the physical world; and 3) I want simply to pay my respects to the people through whose landscape I am traveling.

CCA: Your fiction and nonfiction texts also draw on indigenous myths and legends. I was wondering how you use these stories in your writing. Do you transcribe existing stories, do you slightly modify them, or do you sometimes create myths of your own?

BL: I try to be very careful about the differences between fiction and nonfiction. At the heart of nonfiction is empirical truth, that is, material the reader can verify for themselves in a source over which the writer has no control. The essence of fiction, on the other hand, is emotional truth, meaning that in fiction, you can get the details of the natural setting wrong, but getting those details wrong, while unfortunate, doesn't undermine the authority of the story itself. I don't, generally speaking, take other people's stories and rewrite them to suit me. As I understand the word "myth," I would say it's not possible for me to write myths (as opposed to folklore). When I appropriate a story from an indigenous culture, I always try to explain what I've done, to give credit, and provide sources.

CCA: What role can native stories play in our relationship to the nonhuman, and especially to animals?

7 BL: Indigenous stories proceed on the basis of a different understanding of the moral universe. In Western stories, the moral universe humans occupy excludes the nonhuman world. In indigenous stories, there is one, shared moral universe. In the Western world, for example, the moral universe does not include animals; and therein, of course, lies an explanation for why animals suffer so terribly in their interactions with humans.

CCA: It seems to me that your writing aims at recreating some sense of community with those that the Western society has excluded, especially indigenous populations and animals. How can storytelling help us reconnect with them?

BL: You just have to listen to the stories and use your imagination.

CCA: You also insist on the physical dimension of writing. In "Restoration" (Winter Count), Mr. Seraut, a Frenchman, repairs books in a North Dakota mansion. He asks the narrator to hold a book and to "listen to the rattle of its pages, to examine the retooling" (12). At the 
very end of the story, the narrator compares his own notes on a page to a "skittering of shore birds" (13). With plays on rhythm and sound, unexpected images and the use of lists, your texts often acquire a vibrating quality, as if to show that words can link us to the natural world they describe...

BL: I do pay close attention to the rhythm of my prose and to the kinds of images I employ, with the hope of bringing the reader more deeply into the scene. Much modern prose, it seems to me, demonstrates little interest in this kind of thing, in measured, metric writing, figurative language, and parable, all of which, of course, are mnemonic devices.

CCA: In the same story, De Crenir's library includes copies of Montaigne, Lewis and Clark, Michaux. What does your own library look like? Who are the authors who have influenced you the most?

BL: I should say that "Restoration," and many other stories I have written, are, naturally, representations of those things that preoccupy me as an artist. As for my own library, there are thousands of volumes here at the house and I'd be hardpressed to say which authors have influenced me the most. Every book I read shifts the way I understand the world I'm living in.

CCA: In "Renegotiating the contracts," you comment on the disastrous consequences of separating our species from the rest of the natural world. You declare that if we manage to be more attentive and respectful to the animals' modes of being, and to recreate a sense of wonder towards the nonhuman, we can reconnect with the natural world. In Apologia, you suggest that we can renew our bonds with animals through simple rituals. You write that removing dead animals from the road is "a mark of respect" and a "technique of awareness." Literature is another way to reach a heightened awareness. Indeed, when a writer carefully presents the variety of ways animals inhabit the world and reproduces them, they express that they are worth being described, and thus preserved. According to you, what role can literature, and more particularly fiction, play in environmental activism?

BL: This is a very difficult question to be precise about. I think it's dangerous to assume a writer has an intention in writing a story. I am not aware of ever having written a short story with the intention of making a point, about anything, so if you would ask me what I meant in a story like "Restoration," say, I would answer that I didn't mean anything. I just wanted to tell a story, and the components of that story simply suggested themselves as I was writing. It's hard for me to appreciate how fiction might play a role in environmental activism. For me, literature is an art, and for me the role of the artist, whether we're speaking of music or painting or choreography, is to provide the viewer or reader with an image, a pattern of sound or movement, a narrative, but to offer no explanation. At the heart of all art, I think, are two primary efforts. One is to create a pattern-of tones, of color, of movement-that, because of its coherence, strikes the viewer/listener as illuminating and beautiful. And second, to engage the reader/viewer's imagination so as to stimulate an appreciation of the world outside the self.

CCA: In the same essay, you assert that acknowledging the variety of the animals' particular ways of inhabiting the world allows us to reconnect with other members of our own species. Could you comment on the idea that animals contribute to creating a community of humans?

BL: This is, again, a philosophically difficult question, one that might involve us in an inordinately long answer. What I would say here is that animals have long provided humans with ways to imagine the world beyond the human way. They provide humans with the possibility of a more nuanced, more complex, and loving 
relationship to that world. The mistake we make by investing too heavily in the dictates of the rational mind, is to believe that animals are of no consequence. That they are just part of the scenery, and that, morally, they represent beings whose lives we can dispense with as we see fit.

CCA: The Arctic is not as pristine as it was when you wrote about it in 1989 in Arctic Dreams. Now, there are Arctic cruise operators and climate change has dramatically altered the landscape. Should we now read this text as an elegy?

BL: The idea that Arctic Dreams is now, thirty years after its publication, an elegy, is something I had not thought of. I wrote a new afterword for of Wolves and Men on the 25th anniversary of that book's publication because by then we had a more precise understanding of wolf biology and ecology, and because topics that were not important at the time I wrote that book had since become quite important, like wolf reintroduction. I was never asked to "update" Arctic Dreams because my intent with that book was to evoke the place, to warn that the future of this region was problematic, and to hope that, by describing it in a certain way, people would begin to ask for-or actually write-a book like this whose subject was, say, Africa, or the Eurasian steppes, or Japan. Trying to update Arctic Dreams would be like trying to update a novel.

CCA: You describe animals that most of your readers will never encounter (the polar bear, the narwhal), but you also pay close attention to animals we can see everyday without noticing them. I think of the bodies of road-killed animals, such as badgers and deer (Apologia). How do you consider this interplay between "exotic" and common species in your writing? To what extent are they interconnected?

BL: I don't know that I've ever thought about this question, the division between wild animals and the world of domestic, or suburban, animals. I suppose in describing the world that wild animals live in, I am trying to offer models for contemplation, which I hope readers will remember when they see, say, squirrels scampering in a city park. You're right-there is an interconnection between the animals that are part of our urban and domestic lives, and wild animals. What's important to consider here, I think, is to look at this borderland, the one feral animals live in-and ask ourselves, "What have human beings created here?" or "What are our responsibilities in these two worlds: the world of the sewer rat and that of the grizzly bear?" I should also point out that many "wild" animals are not free animals. In the age of ecotourism, some animals, while still living in "the wild," are presented daily to tourists by guides. A category I therefore maintain in my mind as I watch the disintegration of the natural world around me during the Anthropocene is the difference between the free animal and the wild animal. The physical and intellectual stimulation I feel in an encounter with a free animal is overpowering. In an encounter with a wild animal, one not free to keep its own schedule and follow its own desires, the stimulation remains exciting and elevating, but is not as affecting. When I write about animals, my conscious goal is to enter a state of profound wonder and respect, and, insofar as I can turn those perceptions and emotions into language, to compel the reader to consider the dimensions of their own lives in a similar way.

CCA: In an essay, Aaron Moe suggests that poetic creation is not a purely human affair. Animals participate in the making and the shaping of poetry because they have creative modes of living: "[N]onhuman animals (zoion) are makers (poiesis), and they have agency in that making. The etymology [of zoopoetics] also suggests that when a poet undergoes the making process of poiesis in harmony with the gestures and vocalizations of nonhuman 
animals, a multispecies event occurs. It is a co-making. A joint venture" (2). Do you agree with this idea? Do you feel that the ways of being of the animals you describe so thoroughly participate in your creative process?

BL: This question is a bit too esoteric for me. I very infrequently think about what is going on when I write. I simply write. But I would agree that the way I have interacted with animals throughout my life, I have not only been creating something in words in which they have in some way participated, but in reflecting on those experiences, I have thought, 1) I have been given a gift and, 2) I am in some sense these animals' courier, bringing back to the human world things that, in my mind, I believe humans have misplaced or thrown away or ignored, and are now in desperate need of as they attempt to create a politics and forms of social organization better suited to meeting the enormous problems we face in the Anthropocene.

CCA: I would like to talk about anthropomorphic images. Anthropomorphism testifies to an anthropocentric perspective on the world, but it also amounts to one of the best means writers have to show the links between humans and animals and to express their empathy towards the nonhuman world. Many critics have noticed that nature writers make a conscious and critical use of anthropomorphism. For example, Thomas Pughe explains that the "brute neighbor" metaphor allows Thoreau to adopt a non-anthropocentric point of view, halfway between a symbolic appropriation and an objectivist separation, which shows the author's proximity with animals while acknowledging the otherness of the nonhuman $(2013,254)$. Could you comment on the use of anthropomorphic images in your writing?

BL: I don't think much about anthropomorphism, partly, I suppose, because the kneejerk response of some people to anthropomorphic imagery, which is to insist that it's invalid, primitive, uninformed, or juvenile, is something I find unenlightened and tedious. Minds that are literal and have difficulty with extended metaphors are the kinds of minds that most seem to get up-in-arms about anthropomorphic imagery. I don't think twice about having words of wisdom emanating from the nonhuman world, or "projecting," as some would have it, emotions like love onto the nonhuman world. When I wrote Crow and Weasel, I moved through a world in which animals were as complex and profound in their being, as nuanced, as humans are in their world. I noticed, however, that at a reading, almost invariably, someone in the audience would ask, "Are Crow and Weasel animals?" The fact that someone would ask such a question leaves me at a loss for words. To ignore the figurative and insist on the literal is not a good frame of mind to bring to the reading of fiction.

CCA: You often collaborate with other artists, and some of your books are illustrated with photographs, woodcut prints, or engravings. How do you work with artists such as Robin Eschner (Apologia) or Barry Moser (Outside)?

BL: To my way of thinking, no artist (which for me includes writers) owns a story. The story comes to you as a gift, a reality we acknowledge when we speak of "a gifted musician," or "a gifted painter," or "a gifted dancer." So my collaborations with people like the painter Robin Eschner, or the American composer John Luther Adams, or the woodblock artist Barry Moser, or the theater director Gary Gisselman, are efforts to discover the story I wrote all over again. I'm eager to see what other artists make of something that I wrote and which they like. They might easily present another expression of what you might call the metastory. The story does not belong to me, it's only the expression I've given the story that is mine. 
CCA: You have published many collections of short stories, but no novel or poetry. Why do you particularly work with this genre?

BL: A close friend of mine once told me that I would never write a novel because 1) I have too much respect for people to just use them and throw them away, and 2) that I didn't know how to skate, by which he meant just write on for pages, without saying much of anything. Crow and Weasel is novella length, and I would like to think I have several other novellas within me. I have also outlined a novel, which I have not yet gotten to. I have no gift for poetry, although I am trying to teach myself a Japanese form of prose called haibun, which incorporates haiku between prose passages. To write the kind of prose I write and to write short stories seems to take up most of my creative time, and I'm happy with that.

CCA: You said that your literature is a literature of hope. To conclude this interview, could you speak about the idea that imagination can bring hope in a devastated natural world?

BL: What I meant when I first said that I wanted to participate in the creation of a literature of hope, was that without hope, the world around us will certainly collapse, and while we might then become something else, we will no longer be the species of animal that has brought us to the brink of extinction. At this point hope is not a word that resonates for me. I want to continue to provide illumination and stimulation, and to champion the things that inspire us; but, after fifty-some years of writing and watching the increasingly swift advance of environmental destruction and menace, I feel myself drifting toward the belief that the best that literature can do now is to comfort.

\section{BIBLIOGRAPHY}

Bibliography:

LOPEZ, Barry, Desert Notes: Reflections in the Eye of a Raven, Kansas City, Sheed, Andrews \& McMeel, 1976.

---, Winter Count [1976], New York, Vintage Books, 1981.

---, of Wolves and Men, New York, Scribner, 1978.

---, "Renegotiating the Contracts," Lyon, Thomas J. (ed.), in This Incomparable Land: A Book of American Nature Writing, New York, Penguin, 1989, 381-388.

---, Crow and Weasel, New York, Harper Perennial, 1993.

---, Arctic Dreams: Imagination and Desire in a Northern Landscape [1986], New York, Vintage Books, 2001.

---, “The Naturalist," Orion Magazine, 20.4, 2001, 39-43.

--- and Robin ESCHNER, Apologia, Athens, University of Georgia Press, 1998

--- and Barry MOSER, Outside, San Antonio, Trinity University Press, 2014. 
PUGHE, Thomas, "Brute Neighbors, the Modernity of a Metaphor," in Thoreauvian Modernities: Transatlantic Conversations on an American Icon, Specq, François, Laura Dassow Walls, and Michel Granger, eds., Athens, University of Georgia Press, 2013, 249-263.

MOE, Aaron M., Zoopoetics: Animals and the Making of Poetry, Lanham, Lexington Books, 2013.

SLOVIC, Scott, Seeking Awareness in American Nature Writing: Henry Thoreau, Annie Dillard, Edward Abbey, Wendell Berry, Barry Lopez, Salt Lake City, University of Utah Press, 1992.

INDEX

Subjects: Reconnaissances

\section{AUTHOR}

\section{CLAIRE CAZAJOUS-AUGÉ}

Université Toulouse 2 - Jean Jaurès 